\title{
Diversification opportunities in European stock markets and their impact on textile industry development based on a financial education approach
}

DOI: 10.35530/IT.072.05.1819

\author{
CRISTI SPULBĂR \\ RAMONA BIRĂU \\ VICTOR OLUWI \\ ABDULLAH EJAZ
}

\author{
TIBERIU HORAȚIU GORUN \\ TONI CĂLUGĂRU \\ IMRAN ALI ZULFIQAR \\ LOREDANA ELENA MINEA
}

\begin{abstract}
REZUMAT
Diversification opportunities in European stock markets and their impact on textile industry development based on a financial education approach
\end{abstract}

This research study explores the diversification opportunity among 18 European stock market indices for the sample period from January 2001 to December 2019. However, financial education plays an important role in the development of the textile industry, considering the dynamics of the companies listed on the European stock exchanges. The correlation matrix, pairwise cointegration and Johansen cointegration reveal that selected 18 European stock market indices do not reduces the portfolio risk because exhibit higher positive correlation among them, and their movement pulsed in tandem. Potential investors are attracted by high investment opportunities in order to maximize their return based on portfolio diversification. Financial education can effectively contribute to the sustainable growth of the textile industry in Europe. This empirical research provides an integrated perspective on the long-term evolution of certain major European stock exchange indices. The findings have significant implications for investors interested in selecting these European stock indices in order to diversify their portfolio risk. Our study also imply that selected stock indices have been strongly affected by similar political and financial belies across Europe thus, eliminating the possibility of portfolio risk diversification.

Keywords: portfolio diversification, correlation, Johansen cointegration, textile industry, financial education, stock market

\section{Oportunități de diversificare pe piețele bursiere europene și impactul acestora asupra dezvoltării} industriei textile pe baza unei abordări privind educația financiară

Acest studiu de cercetare analizează oportunitatea de diversificare existentă între 18 indici bursieri europeni pentru perioada de eșantionare cuprinsă între ianuarie 2001 și decembrie 2019. Cu toate acestea, educația financiară joacă un rol important în dezvoltarea industriei textile, având în vedere dinamica companiilor cotate pe piețele bursiere din Europa. Matricea de corelație, cointegrarea pereche și cointegrarea de tip Johansen relevă faptul că cei 18 indici bursieri europeni selectați nu reduc riscul de portofoliu, deoarece prezintă o corelație pozitivă ridicată între ei și mișcarea lor pulsează în tandem. Investitorii potențiali sunt atrași de oportunitățile investiționale semnificative pentru a-și maximiza rentabilitatea pe baza diversificării portofoliului. Educația financiară poate contribui în mod eficient la creșterea sustenabilă a industriei textile din Europa. Această cercetare empirică oferă o perspectivă integrată asupra evoluției pe termen lung a anumitor indici bursieri majori din Europa. Constatările au implicații semnificative pentru investitorii interesați să selecteze acești indici bursieri europeni pentru a-și diversifica riscul de portofoliu. Studiul nostru implică, de asemenea, că indicii bursieri selectați au fost puternic afectați de perturbațiile din zona politică și financiară, similare în toată Europa, eliminând astfel posibilitatea diversificării riscului de portofoliu.

Cuvinte-cheie: diversificarea portofoliului, corelație, cointegrarea de tip Johansen, industria textilă, educația financiară, piața bursieră

\section{INTRODUCTION}

Bullón Pérez et al. [1] highlighted the linkage between textile industry and the real economy based on the production of fibres, yarns, fabrics, clothing and textile goods for domestic, decoration, technical and industrial purpose of consumption. According to Tsa [2] traditional textile industry remains a labourintensive process, while the outcome constitutes a result of yarn spinning, weaving, dyeing and finishing. Moreover, Bullón Pérez et al. [3] argued that effective scheduling and planning in the case of textile industry is a very challenging issue considering that serious foreign competition influences the evolution of the market. Negoita et al. [4] suggested that textile and leather industry sector faces a number of threats, but a variety of opportunities can be exploited based on suitable management strategies. Küsters et al. [5] argued that smart textile products discharge a high growth potential, but companies in the related business sectors like textile machinery, automotive suppliers, and synthetic fibre manufactures have a 
significant contribution to the development of the textile industry. Many of these companies are listed on stock exchanges from all over the world, including in Europe. It was suggested that the fierce competition generated by globalization has various implications for textile and garment manufacturers which resort to lower production costs, increase their efficiency and to create leaner value-adding processes.

Financial education programs are efficient in providing an optimal level of knowledge. Thus, new development alternatives for the textile sector in Europe can be identified. International investors focus on potential correlation between stock returns of different national capital markets in order to diversify portfolio risks by allocating financial asset investments [6]. Liivamägi [7] stated that education is perceived as a main factor determining portfolio diversification options of investors considering that it is correlated with investor risk-taking behaviour on the stock market. This research article provides an applied framework on investment opportunities based on portfolio diversification based on selected European stock market indices. Understanding the behaviour of stock markets requires a certain level of financial education. The textile industry can achieve a higher level of sustainable development by implementing financial education programs. This research study involves an interdisciplinary approach based on a complex empirical investigation focused on broadening the horizon of investment knowledge that could contribute to the growth of the European textile sector. Portfolio diversification in global financial market indices is a well-known practice among various investors to diversity their portfolio risk by holding risk factor constant and maximizing their portfolio returns and vice versa. Finance literature carries a stream of studies to ascertain the possible opportunities available to diversify the portfolio risk among stock market indices. One possible way to study such interplay consists of estimating cointegration among stock market indices. For instance, if stock market indices have low or negative correlation to each other and also cointegrated then they provide favourable diversification opportunities. Segmented stock markets are more promising for portfolio diversification rather than integrated stock market [8, 9]. Previous literature explores the integration among developed stock markets [8], developed with developing stock markets $[10,11]$, developing market with developing markets $[12,13]$ and among regional financial markets [9]. We explore the diversification opportunities in 18 selected stock market indices in Europewhich allow us to examine opportunity of integration among market that located in same geographical region, however, varies in terms of their regulatory bodies and development phases. Our data of 18 stock indices are subject to non-stationary therefore cointegration Vector Autoregression (VAR) lag length is used as a selection criterion to estimate the cointegration among 18 sample stock indices. Analogous to past studies, all 18 stock indices are highly correlated to each other that provide first evidence against diversification among these stocks.

Furthermore, Multivariate Johansen's Co-integration test also confirms the absence of any cointegration equation. Nevertheless, pairwise cointegration test echoes the existence of cointegration among many stock indices however, they will not help to reduce portfolio risk as correlation indicates they move in the same direction and their movements are tandem. For instance, if we construct a portfolio based on Stoxx Europe $600 \mathrm{E}$ and FTSE Europe $100 \mathrm{E}$ which has a correlation coefficient 0.99 , there is a pairwise cointegration and there is a significant causality as well. However, it will not reduce portfolio risk as both indices have positive higher correlation which means both are tandem.

\section{LITERATURE REVIEW}

Markowitz [14] designed the modern portfolio theory in order to diversify and reduces the risk associated to investment. However, the extent to which a risk can be reduced not only depends upon the correlation among securities returns, with in the portfolio, but also correlation between portfolio returns and the economy as a whole in which these securities are being bought and sold. Spulbar et al. [15] suggested that portfolio diversification investment strategy plays a key role in managing stock market risks. Moreover, Spulbar and Birau [16] highlighted that volatility does not diverge to infinity but apparently it is characterized by a very different reaction depending on high positive or high negative stock returns. The effect of globalization, changes in technology and financial innovations in financial markets were highly debated in the era of 1970's, and established that the trends are higher level to take advantage from cross border diversification. Thus, investors started investing into foreign companies to diversify their portfolios. By diversifying their portfolios internationally, these investors also earn capital gain through exchange rate fluctuations. According to World Bank report financial markets around the world now becoming international stock market places that provide an opportunity to investors to fully diversify their portfolios in various developing countries to achieve higher returns with minimized level of risk. Bodie et al. [17] found that internationally diversified portfolios have risk less than half of the risk associated to the portfolios that have been diversified by only US based securities. There have been many studies subject to empirical tests to examine the relationship between stocks in the United States and stock market around the world [18]. The fundamental reason behind comparing world stock markets with the United States is the fact that the United States has not only been a major investor in many countries but also enforces an enormous political and technological influence on countries across the world. This is the reason that the United States has been considered a main driving force for the world major stock markets. Maldonado and Saunders [19] examine inter-temporal trends of 
the correlation coefficients between the monthly stock returns on the United States based index with the monthly stock returns of indices based in Germany, United Kingdom, Canada and Japan from 1957 to 1978. The evidence supports the existence of predictable relationship between these countries in the short run; however, the weak and unstable correlation is present in the stock markets in the long run. Another study, Eun and Shim [20] analysed nine major stock markets around the world, namely, the United States, the United Kingdom, Australia, France, Hong Kong, Canada, Germany, Japan and Switzerland, and conclude that all these international stock market follow the United State stock market. On the other hand, Bessler and Yang [8] established that the United State stock markets are also influenced by the United Kingdom, Hong Kong, France, Germany and Switzerland stock markets. These findings are in line with the increasing rate of integration of world economies with the United States. These international markets are neither fully integrated nor fully segmented which imply a potential opportunity for investment diversification. Numerous studies investigate the various stock markets to establish integration among them, such as Ripley [21] studied the covariance between stock prices around 19 developed stock markets and find stock prices partly move uncorrelated to stock prices of other stock market. Panton et al. [22] found weekly stock prices exhibit stronger relationship among the stock markets of Canada, Netherlands, Belgium, United States and Switzerland whereas lesser strong relationship is found among France and Belgium, Germany and Netherlands and England and Australia. On the other hand, Spulbar and Birau [23] argued that stock market interdependencies are a significant pillar in terms of international portfolio diversification.

Arshanapalli and Doukas [24] examined Japan, United Kingdom, Germany, France and United States stock markets from 1980 to 1990 and found interdependence among daily stock prices of these stock markets with an incremental effect since 1987 except Nikkei Index Japan. Corhayet et al. [25] studied Australia, Singapore, Japan, Hong Kong and New Zealand and found no evidence of a single trend among these countries. Cheung and Mak [26] found causal relationship between Asian and United States and Japan stock markets where Asian stock markets are led by United States stock market. A cointegration test provides evidence that Hong, Kong, South Korea, Singapore, Taiwan, United States and Japan stock markets have weak form of market efficiency where investors can obtain profits from international diversification. Furthermore, Kwan et al. [27] examined Australia, South Korea, Hong Kong, Taiwan, Japan, Singapore, United Kingdom, Germany and the United States stock markets. They find a lead-lag relationship among these stock markets which imply that these markets are not weak form efficient. DeFuscoet al. [28] found no cointegration among United States and emerging Asian stock markets of Thailand, Malaysia, Hong Kong, Taiwan, Korea,
Singapore, and the Philippines in the 1980s and early 1990s. Korajczyk [29] found developing stock market are more segmented as compared to developed stock markets which provides an opportunity for diversification.

Ghosh et al. [30] applied cointegration theory on daily stock prices of Asia Pacific stock market to identify whether these markets are driven by Japan and United States. The results indicate that Indian, Malaysia, Korea and Hong Kong stock market exhibits long run equilibrium relationship with U.S. stock markets. Whereas Singapore, Philippines and Indonesia stock markets are related to Japan stock market. Taiwan and Thailand stock markets are influenced by both Japan and U.S. stock markets. Tuluca and Zwick [31] applied Granger causality test on stock indices on Asian and non-Asian stock markets before and after the financial crises of 1997 . They find that the co-movement of stock prices among these is stronger in Asian financial crises of 1997 than before. Antonio [32] studied long run relationship in European stock markets through a co-integration test. The results reveal that there is not long run relationship among these European stock markets. Plummer and Reid [33] found Thailand, Indonesia, Malaysia, Singapore and Philippines stock markets are completely integrated and investors cannot attain benefits of diversification in these countries.

Error correction vector autoregression (VAR) and cointegration tests Chen et al. [13] found limited aspects to diversify risk in Latin American stock markets. Hardouveliset al. [34] investigated the existence of integration between stock market in eleven European Union countries and UK stock markets. They find higher integration in late 90 that leads to the formulation of EMU but UK stock market is not found to be integrated with other European Union stock markets. Partial correlation-based networks were used to estimate the linkages between global equity markets. Singh et al. [9] revealed that regional markets are more correlated while the negative correlations exist in global markets providing diversification opportunities.

\section{DATA AND METHODOLOGY}

The section sheds light on data and elaborates the methodology. We collected daily data of 18 stock market indices for Europe from $1^{\text {st }}$ of January 2001 to $13^{\text {th }}$ December 2019 from Data Stream. The selected European stock market indices are the following: STOXX EUROPE 600 E, EURONEXT 100, NEXT 150, FTSE EUROTOP 100 E, FTSEUROFIRST 80 E, STOXX EUROPE LARGE 200, STOXX EUROPE SMALL 200, STOXX EUROPE MID 200, FTSE W EUROPE E, MSCI EUROPE E, FTSE EPRA Nareit DEV EUROPE, MSCI EUROPE:SE, EMIX GLOBAL MINING EUROPEAN E, EMIX SMALLER EUROPE AER\&DEF E, EMIX SMALLER EUROPE BANKS E, EMIX SMALLER EUROPE BASIC MAT E, EMIX SMALLER EUROPE BEV\&TOB $E$, and EMIX SMALLER EUROPE BUS PROV E. To ascertain the 
benefits of portfolio diversification, it is important that stock must possess certain characteristics. If two stock indices have higher negative correlation, they will reduce the standard deviation or the portfolio risk [35]. In this vein current study will estimates pairwise correction to have a first glimpse of interplay among 18 stock market indices. Then multiple and pairwise cointegration and Granger causality integration will be examined. The following test will be applied to ascertain the opportunity of diversification among 18 stock market indices.

\section{Correlation Matrix}

The correlation estimates the relationship between two stock market indices. The correlation coefficient runs between +1 to -1 where +1 indicates positive movement between two indices and their relationship is tandem whereas -1 exhibits negative movement. Nevertheless 0 indicates no relationship at all. For portfolio diversification it is important that two indices must have negative interplay to reduce portfolio risk. The relationship between correlation and portfolio risk is estimated through following equations:

$$
\begin{aligned}
\operatorname{Var}\left(R_{p}\right)= & \omega_{i}^{2} \operatorname{var}\left(R_{i}\right)+\omega_{j}^{2} \operatorname{var}\left(R_{j}\right)+ \\
& +2 \omega_{i} \omega_{j} \operatorname{cov}\left(R_{i} R_{j}\right)
\end{aligned}
$$

where $\operatorname{Var}\left(R_{p}\right)$ is variance of Portofolio returns, $\omega_{i}^{2}-$ weights of stock $i$ in portofolio, $\operatorname{cov}\left(R_{i} R_{j}\right)$ - covariance between stock $i$ and stock $j$, which is calculated through following equation:

$$
\operatorname{cov}\left(R_{i} R_{j}\right)=S D\left(R_{j}\right) * S D\left(R_{j}\right) * \operatorname{cor}\left(R_{i} R_{j}\right)
$$

Thus, a lower or negative correlation between two stocks reduces portfolio risk.

\section{Unit Root Test}

It is precursor for cointegration that all the data should be stationary at same level. To obtain the existence of unit root test we apply Dickey Fuller Augmented test on time series. The null hypothesis states that data is stationary. The test estimates the following equation:

$$
Y_{t}=\varphi Y_{t-1}+\mu_{t}
$$

Where $Y_{t}$ is stock market index for a given day, $Y_{t-1}$ - stock market index for previous day, $\varphi$ - coefficient and $\mu_{t}$ - error term.

\section{Johansen's Multivariate Co Integration Test}

Two or more indices are said to be co-integrated with each other if their movements are tandem. This test examines if two or more indices are co-integrated with each other or not in short run and long run. Johansen's Multivariate Co Integration Test uses the following equation in this regard:

$$
\lambda \text { trace }=-T \sum \ln (1-\lambda i)
$$

where $\lambda i$ is estimated eigen value and $\lambda$ trace - trace statistic.

\section{Granger Causality Test}

This test examines if one index causes another index. This "cause" can be unidirectional or bidirectional. If it is unidirectional it means that one index causes another index. If the causality is bidirectional it means that both variables are causing each other.

\section{EMPIRICAL ANALYSIS AND RESULTS}

This section provides empirical findings whether the 18 stock market indices echo the possibility of diversification. Table 1 encapsulates the summary statistics for international indices across 18 stock markets. Total number of observations for each index is 4944. Emix Smaller Europe Bus Prov E and Emix Smaller Europe BEV\&TOB E generate on average greater returns with the highest mean returns of 0.05 whereas lowest mean returns 0.0 belongs to Emix Smaller Europe Banks E (please write country name here). The standard deviation ascertains the level of risk associated to each index. In this precept the returns of Emix Global Mining European E (country name) index exhibit greater risk, around 2.10, as opposed to the risk related to EMIX Smaller Europe Bus Prov E and Emix Smaller Europe Bev\&Tob E which is 0.98. Index that has greater level of risk experiences wider level of variation between minimum returns $(-15.85)$ and maximum returns (18.27). The same can also be observed that lowest return variation with maximum (minimum) returns (8.55) -6.56 are associated to the indices that have lower level of risk. Table 1 infers that Emix Smaller Europe Bus Prov E and Emix Smaller Europe Bev\&Tob $E$ yield higher level of returns with lowest level of risk whereas all indices that have lower returns associated with higher risk. Table 1 also shows lower (higher) level of risk is associated to index that have greater (lower) mean returns. The correlation among the 18 selected stock indices reveals if two stock indices behave independent to each other or there is some level of association exits. The degree of association between two variables is measured through correlation coefficient between +1 to -1 where +1 infer perfect positive and -1 indicates perfect negative relationship between two indices and no relationship if correlation coefficient is 0 . However, for portfolio diversification there should be some level of correlation required to diversify the risk. Fabozziet al. [35] show portfolio standard deviation decreases, keeping expected returns constant, when correlation between two assets decreases. It can be observed from our empirical analysis that majority of the sample stock indices have higher correlation, which are in tandem. By investing in such stocks will not decrease portfolio risk. Substantial amount of literature support application of Dickey Fuller test before using co-integration between two series. Co-integration among indices requires that time series must be stationary at same level to rule out the possibility of any growth within the series. To confirm the stationarity level of each index, table 2 includes the results for Augmented Dickey Fuller test for each index at level 0 and level 1. 


\begin{tabular}{|c|l|c|c|c|c|c|}
\hline \multicolumn{7}{|c|}{ DESCRIPTIVE STATISTICS } \\
\hline Sr. no. & \multicolumn{1}{|c|}{ Index name } & No. of obs. & Mean & Std. Dev. & Min & Max \\
\hline 1 & STOXX EUROPE 600 E & 4944 & 0.01 & 1.18 & -7.62 & 9.87 \\
\hline 2 & EURONEXT 100 & 4944 & 0.01 & 1.28 & -8.56 & 10.87 \\
\hline 3 & NEXT 150 & 4944 & 0.03 & 1.08 & -7.76 & 8.88 \\
\hline 4 & FTSE EUROTOP 100 E & 4944 & 0.01 & 1.23 & -7.86 & 10.33 \\
\hline 5 & FTSEUROFIRST 80 E & 4944 & 0.01 & 1.37 & -8.12 & 11.28 \\
\hline 6 & STOXX EUROPE LARGE 200 & 4944 & 0.01 & 1.21 & -7.85 & 10.32 \\
\hline 7 & STOXX EUROPE SMALL 200 & 4944 & 0.02 & 1.11 & -7.72 & 7.32 \\
\hline 8 & STOXX EUROPE MID 200 & 4944 & 0.02 & 1.13 & -8.05 & 8.17 \\
\hline 9 & FTSE W EUROPE E & 4944 & 0.01 & 1.19 & -7.70 & 10.13 \\
\hline 10 & MSCI EUROPE E & 4944 & 0.01 & 1.18 & -7.61 & 10.05 \\
\hline 11 & FTSE EPRA Nareit DEV EUROPE & 4944 & 0.02 & 1.12 & -8.95 & 7.40 \\
\hline 12 & MSCI EUROPE :S E & 4944 & 0.03 & 1.02 & -7.63 & 7.25 \\
\hline 13 & EMIX GLOBAL MINING EUROPEAN E & 4944 & 0.04 & 2.10 & -15.85 & 18.27 \\
\hline 14 & EMIX SMALLER EUROPE AER\&DEF E & 4944 & 0.04 & 1.24 & -6.89 & 6.12 \\
\hline 15 & EMIX SMALLER EUROPE BANKS E & 4944 & 0.00 & 1.12 & -11.48 & 9.61 \\
\hline 16 & EMIX SMALLER EUROPE BASIC MAT E & 4944 & 0.03 & 1.12 & -7.99 & 8.08 \\
\hline 17 & EMIX SMALLER EUROPE BEV\&TOB E & 4944 & 0.05 & 0.98 & -6.56 & 8.55 \\
\hline 18 & EMIX SMALLER EUROPE BUS PROV E & 4944 & 0.05 & 0.98 & -6.56 & 8.55 \\
\hline
\end{tabular}

\begin{tabular}{|c|c|c|c|c|c|c|c|}
\hline \multicolumn{8}{|c|}{ STATIONARITY DIAGNISTIC: UNIT ROOT TEST AT LEVEL 0 AND LEVEL 1} \\
\hline \multirow{2}{*}{ Index name } & \multirow{2}{*}{$\begin{array}{c}1 \% \text { Critical } \\
\text { value }\end{array}$} & \multicolumn{2}{|c|}{ Level 0} & \multirow{2}{*}{ Remarks } & \multicolumn{2}{|c|}{ Level 1} & \multirow{2}{*}{ Remarks } \\
\hline & & t-stat & prob. & & t-stat & prob. & \\
\hline STOXX EUROPE $600 \mathrm{E}$ & -3.43 & -1.57 & 0.4987 & Non-stationary & -70.48 & 0 & Stationary \\
\hline EURONEXT 100 & -3.43 & -1.571 & 0.498 & Non-Stationary & -70.771 & 0 & Stationary \\
\hline NEXT 150 & -3.43 & -0.208 & 0.9376 & Non-Stationary & -63.563 & 0 & Stationary \\
\hline FTSE EUROTOP $100 \mathrm{E}$ & -3.43 & -2.781 & 0.061 & Non-Stationary & -72.081 & 0 & Stationary \\
\hline FTSEUROFIRST $80 \mathrm{E}$ & -3.43 & -2.764 & 0.0636 & Non-Stationary & -71.978 & 0 & Stationary \\
\hline STOXX EUROPE LARGE 200 & -3.43 & -2.184 & 0.2121 & Non-Stationary & -71.479 & 0 & Stationary \\
\hline STOXX EUROPE SMALL 200 & -3.43 & -0.288 & 0.9271 & Non-Stationary & -66.138 & 0 & Stationary \\
\hline STOXX EUROPE MID 200 & -3.43 & -0.272 & 0.9294 & Non-Stationary & -67.014 & 0 & Stationary \\
\hline FTSE W EUROPE E & -3.43 & -1.764 & 0.3986 & Non-Stationary & -70.635 & 0 & Stationary \\
\hline MSCI EUROPE E & -3.43 & -1.832 & 0.3648 & Non-Stationary & -70.71 & 0 & Stationary \\
\hline $\begin{array}{l}\text { FTSE EPRA Nareit DEV } \\
\text { EUROPE }\end{array}$ & -3.43 & 1.185 & 0.6798 & Non-Stationary & -66.408 & 0 & Stationary \\
\hline MSCI EUROPE :S E & -3.43 & 0.083 & 0.9649 & Non-Stationary & -63.987 & 0 & Stationary \\
\hline $\begin{array}{l}\text { EMIX GLOBAL MINING } \\
\text { EUROPEAN E }\end{array}$ & -3.43 & -2.163 & 0.22 & Non-Stationary & -69.65 & 0 & Stationary \\
\hline $\begin{array}{l}\text { EMIX SMALLER EUROPE } \\
\text { AER\&DEF E }\end{array}$ & -3.43 & -0.379 & 0.9135 & Non-Stationary & -65.79 & 0 & Stationary \\
\hline $\begin{array}{l}\text { EMIX SMALLER EUROPE } \\
\text { BANKS E }\end{array}$ & -3.43 & -0.743 & 0.8353 & Non-Stationary & -64.421 & 0 & Stationary \\
\hline $\begin{array}{l}\text { EMIX SMALLER EUROPE } \\
\text { BASIC MAT E }\end{array}$ & -3.43 & -1.148 & 0.6956 & Non-Stationary & -62.473 & 0 & Stationary \\
\hline $\begin{array}{l}\text { EMIX SMALLER EUROPE } \\
\text { BEV\&TOB E }\end{array}$ & -3.43 & 0.678 & 0.9894 & Non-Stationary & -67.63 & 0 & Stationary \\
\hline $\begin{array}{l}\text { EMIX SMALLER EUROPE } \\
\text { BUS PROV E }\end{array}$ & -3.43 & -0.332 & 0.9208 & Non-Stationary & -63.385 & 0 & Stationary \\
\hline
\end{tabular}

Note: $1 \%$ Critical value $=-3.430$. 
The null hypothesis suggests the presence of unit root within the series. All the indices are non-stationary at level 0 because their probability value is not less the 0.05 which does not reject the null hypothesis. Moreover, table 2 presents critical values -3.43 at $1 \%$ level of significance. To make data stationary at level 0 , the t-statistics should be less -3.43 along with the $p$-value less than 0.05 . Nevertheless, it can be observed that even t-statistics are less than critical values but still probability value fails to reject the null hypothesis. However, all indices are stationary at level 1 indicated by p-values less than 0.05 and $\mathrm{t}$-statistics are also less than the critical values -3.43 . Hence, rejecting the null hypothesis it can be inferred that all indices does not contain unit root at level 1. For instance, Bouriet et al. [36] also applied same test before estimating co-integration among Indian stock market and gold and oil sector. Cheong [38] study weak form of market efficiency through unit root test. Similarly, Alamet et al. [32] use Dickey Fuller test to estimate the level of stationarity to examine the sectoral efficiency of Islamic stock indices. Thus, the significance of using unit root test is well justified and verified by past studies.

Lag length number is determined in table 3 which is a prerequisite to run co-integration and granger causality test. VAR leg length test is utilized to estimate the number of lag length for further use of cointegration and granger causality. Table 3 includes 5 selection criteria to determine the lag length namely, LR test statistics, Final Predication Error, Akaike information criterion, Schwarz Bayesian information criterion and Hannan-Quinn information criterion. As a rule of thumb, the lag length should be the one that is supported by maximum number of selection criteria however, if two lag lengths are supported by same number of selection criteria then we select the one which is justified by AIC. Table 3 indicates that lag length 3 and lag length 1 are supported by AIC, FPE and HQIC, SBIC, respectively. We will select lag length 3 as it is justified by AIC for co-integration and granger causality tests.

Multivariate cointegration is estimated in table 4 to confirm whether stock market indices are cointegrated to

Table 3

\begin{tabular}{|c|c|c|c|c|c|c|c|c|}
\hline \multicolumn{10}{|c|}{ VAR LAG LENGTH SELECTION CRITERIA } \\
\hline Lag & LL & LR & df & p-vale & FPE & AIC & HQIC & SBIC \\
\hline 0 & -3099.27 & - & - & - & $2.30 E-22$ & 1.26205 & 1.27037 & 1.28576 \\
\hline 1 & -1497.61 & 3203.3 & 324 & 0 & $1.40 E-22$ & 0.744781 & $0.90272^{*}$ & $1.19514^{*}$ \\
\hline 2 & -1010.54 & 974.15 & 324 & 0 & $1.30 \mathrm{E}-22$ & 0.67876 & 0.986324 & 1.55577 \\
\hline 3 & -660.965 & 699.14 & 324 & 0 & $1.3 \mathrm{e}-22^{*}$ & $0.668407^{*}$ & 1.1256 & 1.97206 \\
\hline 4 & -377.997 & $565.94^{*}$ & 324 & 0 & $1.30 \mathrm{E}-22$ & 0.685019 & 1.29184 & 2.41533 \\
\hline
\end{tabular}

Note: * indicates lag order selected by the criterion.

Table 4

\begin{tabular}{|c|c|c|c|c|c|}
\hline \multicolumn{7}{|c|}{ MULTIVARIATE JOHANSEN'S CO-INTEGRATION TEST } \\
\hline Maximum rank & Parms & LL & Eigenvalue & Trace statistic & 5\% Critical value \\
\hline 0 & 666 & -139928 & - & $817.9442^{*}$ & - \\
\hline 1 & 701 & -139864 & 0.02538 & 690.8987 & - \\
\hline 2 & 734 & -139814 & 0.01998 & 591.1404 & - \\
\hline 3 & 765 & -139766 & 0.01915 & 495.6026 & - \\
\hline 4 & 794 & -139727 & 0.01572 & 417.3083 & - \\
\hline 5 & 821 & -139692 & 0.01399 & 347.6826 & - \\
\hline 6 & 846 & -139663 & 0.01168 & 289.6405 & - \\
\hline 7 & 869 & -139636 & 0.01094 & 235.2588 & 277.71 \\
\hline 8 & 890 & -139613 & 0.00929 & 189.1251 & 233.13 \\
\hline 9 & 909 & -139594 & 0.00758 & 151.5457 & 192.89 \\
\hline 10 & 926 & -139579 & 0.00624 & 120.6117 & 156 \\
\hline 11 & 941 & -139565 & 0.00576 & 92.0483 & 124.24 \\
\hline 12 & 954 & -139552 & 0.00527 & 65.9468 & 94.15 \\
\hline 13 & 965 & -139542 & 0.00393 & 46.4752 & 68.52 \\
\hline 14 & 974 & -139533 & 0.00361 & 28.5824 & 47.21 \\
\hline 15 & 981 & -139527 & 0.00255 & 15.9416 & 29.68 \\
\hline 16 & 986 & -139522 & 0.0019 & 6.5545 & 15.41 \\
\hline 17 & 989 & -139519 & 0.00132 & 0.0027 & 3.76 \\
\hline 18 & 990 & -139519 & 0 & - & - \\
\hline
\end{tabular}

Note: * indicates co integrated equations. 
each other. According to the criteria the trace value should be less than $5 \%$ critical value. Trace statistics become less than $5 \%$ critical value; the corresponding maximum ranks represent number of cointegration equation. Trace statistics states null hypothesis that stock market indices do not carry any cointegration among them, whereas, alternative hypothesis state that at least one cointegration equation exits. Table 4 shows traces statistics where significant trace statistics are marked with asterisk $\left(^{*}\right)$, but corresponding maximum ranks is 0 . This implies that there is no cointegration equation exits among stock market indices.

Tables 5-7 reveal pairwise cointegration among stock market indices on one-to-one basis. As a rule of thumb trace statistics compared with critical value 15.41 at $5 \%$ level of significance. If trace statistics greater (less) than the critical value, then it proves evidence of presence (absences) of cointegration between two stock indices. Tables 5-7 indicate that there are 31 pairs that exhibit cointegration indicated by 1 , in parenthesis, and remaining indices that are represented by 0 , in parenthesis, are not cointegrated. The stock indices that carry N/S are not significant.

The results of Granger causality test is used to ascertain if one stock market index is related to another stock market index. Granger Causality test formulates null hypothesis that states there is no causality between two stock indices. If the probability value is less than 0.05 , we can reject the null hypothesis. Granger Causality has a brighter side that it only confirms the existence of causality, nevertheless, the dark side is that it does not provide causality coefficient. Our research study provides evidence that majority of the selected stock indices highlights

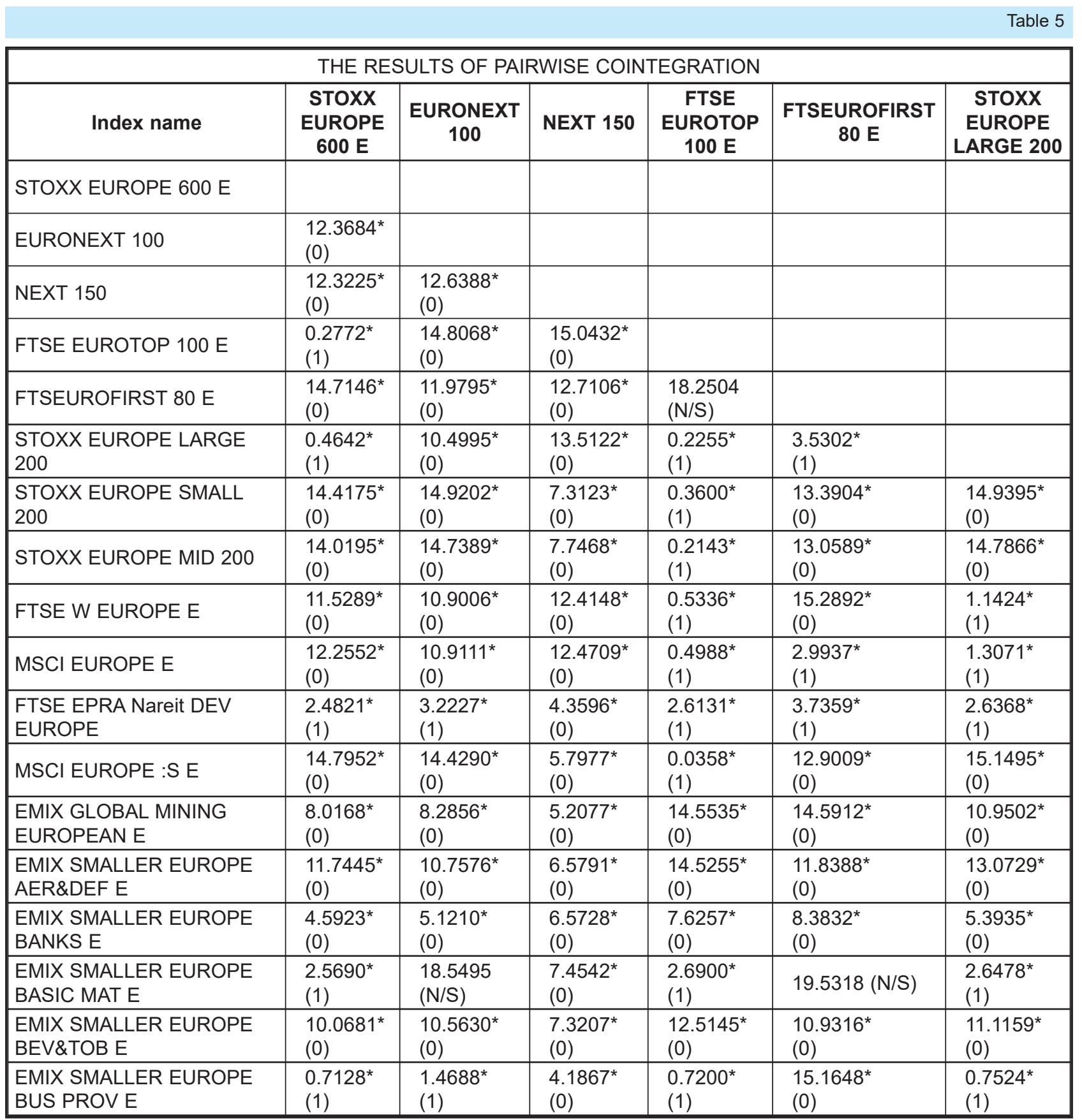




\begin{tabular}{|c|c|c|c|c|c|c|}
\hline \multicolumn{7}{|c|}{ THE RESULTS OF PAIRWISE COINTEGRATION (CONTINUED) } \\
\hline Index name & $\begin{array}{c}\text { STOXX } \\
\text { EUROPE } \\
\text { SMALL } 200\end{array}$ & $\begin{array}{c}\text { STOXX } \\
\text { EUROPE } \\
\text { MID } 200\end{array}$ & $\begin{array}{l}\text { FTSE W } \\
\text { EUROPE E }\end{array}$ & $\begin{array}{c}\text { MSCI } \\
\text { EUROPE E }\end{array}$ & $\begin{array}{c}\text { FTSE EPRA } \\
\text { Nareit DEV } \\
\text { EUROPE }\end{array}$ & $\begin{array}{c}\text { MSCI } \\
\text { EUROPE :S E }\end{array}$ \\
\hline $\begin{array}{l}\text { STOXX EUROPE MID } \\
200\end{array}$ & $\begin{array}{l}12.1571^{*} \\
(0)\end{array}$ & & & & & \\
\hline FTSE W EUROPE E & $\begin{array}{l}14.0840^{*} \\
(0)\end{array}$ & $\begin{array}{l}13.5861^{*} \\
(0)\end{array}$ & & & & \\
\hline MSCI EUROPE E & $\begin{array}{l}14.0369^{*} \\
(0)\end{array}$ & $\begin{array}{l}3.7520^{*} \\
(0)\end{array}$ & $\begin{array}{l}12.4340^{*} \\
(0)\end{array}$ & & & \\
\hline $\begin{array}{l}\text { FTSE EPRA Nareit DEV } \\
\text { EUROPE }\end{array}$ & $\begin{array}{l}3.8491^{*} \\
(0)\end{array}$ & $\begin{array}{l}3.8747^{*} \\
(0)\end{array}$ & $\begin{array}{l}2.6735^{\star} \\
(1)\end{array}$ & $\begin{array}{l}2.5803^{*} \\
(1)\end{array}$ & & \\
\hline MSCI EUROPE :S E & $\begin{array}{l}10.8557^{*} \\
(0)\end{array}$ & $\begin{array}{l}0.0023^{*} \\
(1)\end{array}$ & $\begin{array}{l}14.2878^{*} \\
(0)\end{array}$ & $\begin{array}{l}14.3678^{*} \\
(0)\end{array}$ & $\begin{array}{l}3.7192^{*} \\
(0)\end{array}$ & \\
\hline $\begin{array}{l}\text { EMIX GLOBAL MINING } \\
\text { EUROPEAN E }\end{array}$ & $\begin{array}{l}5.0615^{*} \\
(0)\end{array}$ & $\begin{array}{l}5.0011^{*} \\
(0)\end{array}$ & $\begin{array}{l}8.8782^{*} \\
(0)\end{array}$ & $\begin{array}{l}9.1610^{*} \\
(0)\end{array}$ & $\begin{array}{l}10.4766^{*} \\
(0)\end{array}$ & $\begin{array}{l}5.1446^{*} \\
(0)\end{array}$ \\
\hline $\begin{array}{l}\text { EMIX SMALLER } \\
\text { EUROPE AER\&DEF E }\end{array}$ & $\begin{array}{l}6.9062^{*} \\
(0)\end{array}$ & $\begin{array}{l}6.6450^{*} \\
(0)\end{array}$ & $\begin{array}{l}11.7769^{*} \\
(0)\end{array}$ & $\begin{array}{l}11.8482^{*} \\
(0)\end{array}$ & $\begin{array}{l}2.7155^{*} \\
(0)\end{array}$ & $\begin{array}{l}5.4469^{*} \\
(0)\end{array}$ \\
\hline $\begin{array}{l}\text { EMIX SMALLER } \\
\text { EUROPE BANKS E }\end{array}$ & $\begin{array}{l}6.3064^{*} \\
(0)\end{array}$ & $\begin{array}{l}5.3169^{*} \\
(0)\end{array}$ & $\begin{array}{l}4.9547^{*} \\
(0)\end{array}$ & $\begin{array}{l}4.7194^{*} \\
(0)\end{array}$ & $\begin{array}{l}2.6064^{*} \\
(0)\end{array}$ & $\begin{array}{l}5.5325^{*} \\
(0)\end{array}$ \\
\hline $\begin{array}{l}\text { EMIX SMALLER } \\
\text { EUROPE BASIC MAT E }\end{array}$ & $\begin{array}{l}6.6209^{*} \\
(0)\end{array}$ & $\begin{array}{l}6.2644^{*} \\
(0)\end{array}$ & $\begin{array}{l}2.7154^{*} \\
(1)\end{array}$ & $\begin{array}{l}2.6205^{*} \\
(1)\end{array}$ & $\begin{array}{l}6.2228^{*} \\
(0)\end{array}$ & $\begin{array}{l}10.5148^{*} \\
(0)\end{array}$ \\
\hline $\begin{array}{l}\text { EMIX SMALLER } \\
\text { EUROPE BEV\&TOB E }\end{array}$ & $\begin{array}{l}8.1836^{*} \\
(0)\end{array}$ & $\begin{array}{l}8.3781^{*} \\
(0)\end{array}$ & $\begin{array}{l}10.2130^{*} \\
(0)\end{array}$ & $\begin{array}{l}10.2648^{*} \\
(0)\end{array}$ & $\begin{array}{l}3.2191^{*} \\
(0)\end{array}$ & $\begin{array}{l}6.8033^{*} \\
(0)\end{array}$ \\
\hline $\begin{array}{l}\text { EMIX SMALLER } \\
\text { EUROPE BUS PROV E }\end{array}$ & $\begin{array}{l}4.0632^{*} \\
(0)\end{array}$ & $\begin{array}{l}4.2118^{*} \\
(0)\end{array}$ & $\begin{array}{l}0.7144^{*} \\
(1)\end{array}$ & $\begin{array}{l}0.6966^{*} \\
(1)\end{array}$ & $\begin{array}{l}4.7315^{*} \\
(0)\end{array}$ & $\begin{array}{l}3.0576^{*} \\
(0)\end{array}$ \\
\hline
\end{tabular}

\begin{tabular}{|c|c|c|c|c|c|c|}
\hline \multicolumn{7}{|c|}{ THE RESULTS OF PAIRWISE COINTEGRATION (CONTINUED) } \\
\hline Index name & $\begin{array}{c}\text { EMIX } \\
\text { GLOBAL } \\
\text { MINING } \\
\text { EUROPEAN E }\end{array}$ & $\begin{array}{c}\text { EMIX } \\
\text { SMALLER } \\
\text { EUROPE } \\
\text { AER\&DEF E }\end{array}$ & $\begin{array}{c}\text { EMIX } \\
\text { SMALLER } \\
\text { EUROPE } \\
\text { BANKS E }\end{array}$ & $\begin{array}{c}\text { EMIX } \\
\text { SMALLER } \\
\text { EUROPE } \\
\text { BASIC MAT E }\end{array}$ & $\begin{array}{l}\text { EMIX SMALL- } \\
\text { ER EUROPE } \\
\text { BEV\&TOB E }\end{array}$ & $\begin{array}{c}\text { EMIX } \\
\text { SMALLER } \\
\text { EUROPE } \\
\text { BUS PROV E }\end{array}$ \\
\hline $\begin{array}{l}\text { EMIX SMALLER } \\
\text { EUROPE AER\&DEF E }\end{array}$ & $\begin{array}{l}5.3260^{*} \\
(0)\end{array}$ & & & & & \\
\hline $\begin{array}{l}\text { EMIX SMALLER } \\
\text { EUROPE BANKS E }\end{array}$ & $\begin{array}{l}1.9640^{*} \\
(1)\end{array}$ & $\begin{array}{l}4.2775^{*} \\
(0)\end{array}$ & & & & \\
\hline $\begin{array}{l}\text { EMIX SMALLER } \\
\text { EUROPE BASIC MAT E }\end{array}$ & $\begin{array}{l}7.2135^{*} \\
(0)\end{array}$ & $\begin{array}{l}4.3862^{*} \\
(0)\end{array}$ & $\begin{array}{l}5.1433^{*} \\
(0)\end{array}$ & & & \\
\hline $\begin{array}{l}\text { EMIX SMALLER } \\
\text { EUROPE BEV\&TOB E }\end{array}$ & $\begin{array}{l}5.6800^{*} \\
(0)\end{array}$ & $\begin{array}{l}6.6285^{*} \\
(0)\end{array}$ & $\begin{array}{l}4.4555^{*} \\
(0)\end{array}$ & $\begin{array}{l}6.0293^{*} \\
(0)\end{array}$ & & \\
\hline $\begin{array}{l}\text { EMIX SMALLER } \\
\text { EUROPE BUS PROV E }\end{array}$ & $\begin{array}{l}5.5431^{*} \\
(0)\end{array}$ & $\begin{array}{l}4.7548^{*} \\
(0)\end{array}$ & $\begin{array}{l}5.4579^{*} \\
(0)\end{array}$ & $\begin{array}{l}5.5486^{*} \\
(0)\end{array}$ & $\begin{array}{l}4.7942^{*} \\
(0)\end{array}$ & \\
\hline
\end{tabular}

Note: $5 \%$ for rank $(0)$ critical value $=15.41$; for rank (1) critical value $=3.76,(0)$ indicates no co-integration, $(1)$ indicates co-integration and N/S indicates not significant.

causality linkage among each other. This aspect implies that the change in one index will bring change in another index in the short run.

\section{CONCLUSIONS}

Current study explores the opportunities of portfolio diversification among 18 selected stock market in Europe. For minimizing the portfolio risk, these stock indices must be low or negatively correlation and should be integrated. We apply pairwise correlation, cointegration and pairwise cointegration. Based on our analysis, these 18 sample stock market indices are not an option for investment opportunity because they have higher positive correlation to each other whereas investment in these indices will not reduce portfolio risk. The subsequent analysis such as pairwise cointegration and granger causality test provide further support to our initial prediction. Although pairwise and granger causality establish the relationship among majority of the indices, however, due to higher positive correlation, they move in one direction. For instance, if we construct a portfolio based on 
Stoxx Europe 600E and FTSE Europe $100 \mathrm{E}$ which has a correlation coefficient 0.99 , there is a pairwise cointegration and there is a significant causality as well. However, it will not reduce portfolio risk as both indices have positive higher correlation which means both are tandem. The same pattern applies on all other indices. Future research can be carried out to evaluate diversification opportunities among Asian stock indices or a comparison between Asian and American stock indices. The plausible reason for higher positive correlation is that these stock indices belong to Europe that is almost get affected on a same magnitude by similar political and financial contradictions. Moreover, the controlling regulatory of these 18 stock indices are somehow related to each other and formulate similar policies.

\section{REFERENCES}

[1] Bullón Pérez, J., González Arrieta, A., Hernández Encinas, A., Queiruga-Dios, A.,Manufacturing processes in the textile industry. Expert Systems for fabrics production, In: ADCAIJ: Advances in Distributed Computing and Articial Intelligence Journal, 2017, 6, 1, 41-50

[2] Tsa, W.H., Green Production Planning and Control for the Textile Industry by Using Mathematical Programming and Industry 4.0 Techniques, In: Energies, 2018, 11, 2072

[3] Bullón Pérez, J., González Arrieta, A., Hernández Encinas, A., Queiruga-Dios, A. Industrial Cyber-Physical Systems in Textile Engineering, In: Graña, M., López-Guede, J., Etxaniz, O., Herrero, Á., Quintián, H., Corchado, E. (eds), International Conference on EUropean Transnational Education, Springer, 2016, 527, 126-135

[4] Negoita, O.I., Ghituleasa, C., Negoita, O.D., Purcarea, A.A.,Branding process - An important factor in guiding the company towards success, In: IndustriaTextila, 2015, 66, 2, 103-107

[5] Küsters, D., Praß, N., Gloy, Y.S., Textile Learning Factory 4.0 - Preparing Germany's Textile Industry for the Digital Future, In: 7th Conference on Learning Factories, CLF 2017, Procedia Manufacturing, 2017, 9, 214 - 221

[6] Spulbar, C., Birau, R., Emerging Research on Monetary Policy, Banking, and Financial Markets, In: IGI Global USA, 2019, 322, ISBN13: 9781522592693, ISBN10: 1522592695, EISBN13: 9781522592716, https://doi.org/10.4018/ 978-1-5225-9269-3

[7] Liivamägi, K., Investor education and trading activity on the stock market, In: Baltic Journal of Economics, 2016, $16,2,114-131$

[8] Bessler, D.A., Yang, J., The structure of interdependence in international stock markets, In: Journal of international money and finance, 2003, 22, 2, 261-287

[9] Singh, V., Li, B., Roca, E., Global and regional linkages across market cycles: evidence from partial correlations in a network framework, In: Applied Economics, 2019, 51, 33, 3551-3582

[10] Vo, X.V., Ellis, C., International financial integration: Stock return linkages and volatility transmission between Vietnam and advanced countries, In: Emerging Markets Review, 2018, 36, 19-27

[11] Trivedi, J., Spulbar, C., Birau, R., Mehdiabadi, A., Modelling volatility spillovers, cross-market correlation and comovements between stock markets in European Union: an empirical case study. In: Business, Management and Economics Engineering, 2021, 19, 1, 70-90, https://doi.org/10.3846/bmee.2021.13588

[12] Kocaarslan, B., Sari, R., Gormus, A., Soytas, U., Dynamic correlations between BRIC and U.S. stock markets: The asymmetric impact of volatility expectations in oil, gold and financial markets, In: Journal of Commodity Markets, Elsevier, 2017, 7, C, 41-56

[13] Chen, G.M., Firth, M., Rui, O.M., Stock market linkages: evidence from Latin America, In: Journal of Banking \& Finance, 2002, 26, 6, 1113-1141

[14] Markowitz, H., Portfolio selection, In: The journal of finance, 1952, 7, 1, 77-91

[15] Spulbar, C., Trivedi, J., Birau, R., Investigating abnormal volatility transmission patterns between emerging and developed stock markets: a case study, In: Journal of Business Economics and Management, 2020, 21, 6, 1561-1592, https://doi.org/10.3846/jbem.2020.13507

[16] Spulbar, C., Birau, R., Emerging research on monetary policy, banking, and financial markets, In: IGI Global, USA, 2019, https://doi.org/10.4018/978-1-5225-9269-3

[17] Bodie, Z., Kane, A., Marcus,A.J., Investments, 4th Edition, McGraw Hill, 1999

[18] Phylaktis, K., Ravazzolo, F., Stock market linkages in emerging markets: implications for international portfolio diversification, In: Journal of International Financial Markets, Institutions and Money, 2005, 15, 2, 91-106

[19] Maldonado, R., Anthony, S., International portfolio diversification and the inter-temporal of international stock market relationships 1957-1978, In: Financial Management, 1981, 10, 54-63

[20] Eun, C.S., Sangdal, S., International transmission of stock market movements, In: Journal of Financial and Quantitative Analysis, 1989, 24, 241-256

[21] Ripley, D., Systematic elements in the linkage of national stock market indices, In: The Review of Economics and Statistics, 1973, 15, 356-361

[22] Panton, D.B., Parker, V.L., Joy, O.M., Comovements of international equity markets: A Taxonomic approach, In: Journal of Financial and Quantitative Analysis, 1976, 11, 415-432

[23] Spulbar, C., Birau, R., Testing weak-form efficiency and long-term causality of the R.I.P.H emerging capital markets, In: International Journal of Business Quantitative Economics and Applied Management Research, 2018, 5, 2, 1-19

[24] Arshanapalli, B., Doukas, J., International stock market linkage: Evidence from the pre- and post-October 1987 period, In: Journal of Banking and Finance, 1993, 17, 193-208

[25] Corhay, A., Rad, A., Urbain, J., Long-run behavior of Pacific-Basin stock prices, In: Applied Financial Economics, $1995,5,11-18$

[26] Cheung, Y.L., Mak, S.C., A Study of the international transmission of stock market fluctuation between the developed markets and the Asian-Pacific markets, In: Applied Financial Economics, 1992, 2, 1-5 
[27] Kwan, A.C.C., Ah-boon, S., Cotsomitis, J.A., The causal relationships between equity indices on world exchanges, Applied Economics, 1995, 27, 1, 33-37

[28] DeFusco, R.A., Geppert, J.M., Tsetsekos, G.P., Long-run diversification potential in emerging stock markets, In: Financial Review, 1996, 31, 343-363

[29] Korajczyk, R.A., A measure of stock market integration for developed and emerging markets, In: The World Bank Economic Review, 1996, 10, 2, 267-289

[30] Ghosh, A., Saidi, R., Johnson, K.H., Who moves the Asia-Pacific stock markets - US or Japan? Empirical evidence based on the theory cointegration, In: The Financial Review, 1999, 34, 159-170

[31] Tuluca, S.A., Burton, Z., The effects of the Asian crisis on global equity markets, In: The Financial Review, 2001, 36, 125-142

[32] Alam, N., Arshad, S., Rizvi, S.A., Do Islamic stock indices perform better than conventional counterparts? An empirical investigation of sectoral efficiency,In: Review of Financial Economics, Elsevier, 2016, 31, 108-114

[33] Plummer, M., Reid W.C., Bond market development and integration in ASEAN, In: International Journal of Finance \& Economics, 2005, 10, 2, 133-142

[34] Hardouvelis, G., Malliaropulos, D., Priestley, R., EMU and European Stock Market Integration, In: The Journal of Business, 2006, 79, 1, 365-392

[35] Fabozzi, F., Gupta, F., Markowitz, H., The Legacy of Modern Portfolio Theory, In: The Journal of Investing, 2002, 11, 7-22, https://doi.org/10.3905/joi.2002.319510

[36] Bouri, E., Jain Anshul Biswal, P.C., Roubaud, D., Cointegration and nonlinear causality amongst gold, oil, and the Indian stock market: Evidence from implied volatility indices, In: Resources Policy, 2017, 52, 201-206

[37] Cheong, C.W., A sectoral efficiency analysis of Malaysian stock exchange under structural break, In: American Journal of Applied Sciences, 2008, 5, 1291-1295

\section{Authors:}

\section{CRISTI SPULBĂR ${ }^{1}$, RAMONA BIRĂU², VICTOR OLUWI ${ }^{3}$, ABDULLAH EJAZ, TIBERIU HORAȚIU GORUN ${ }^{2}$, TONI CĂLUGĂRU ${ }^{1}$, IMRAN ALI ZULFIQAR ${ }^{5}$, LOREDANA ELENA MINEA ${ }^{1}$}

${ }^{1}$ University of Craiova, Faculty of Economics and Business Administration, Craiova, Romania e-mail: cristi_spulbar@yahoo.com,toni@advisority.com, loredanaelenaminea@gmail.com

${ }^{2}$ C-tin Brancusi University of Targu Jiu, Faculty of Education Science, Law and Public Administration, Romania e-mail: gorunhoratiu@yahoo.com

${ }^{3}$ Concordia University of Edmonton, Canada e-mail: victor.oluwi@chromeconsultingassociates.com

${ }^{4}$ Department of Anthropology, Economics and Political Science, MacEwan University, Canada and Augustana Campus - University of Alberta, Canada e-mail: ejazabdullah03@gmail.com

5 University of Lahore, Pakistan e-mail: zulfiqaraliimran05@gamail.com

\section{Corresponding author:}

RAMONA BIRĂU

e-mail: ramona.f.birau@gmail.com 